\title{
Léncak: Ruang Sosial-Keagamaan Tokoh Agama Perempuan Madura
}

\author{
Hasanatul Jannah ${ }^{1^{*}}$, Rachmah Ida ${ }^{2}$ \\ 1) Institut Agama Islam Negeri, Surakarta, Indonesia, ${ }^{2)}$ Universitas Airlangga, \\ Surabaya, Indonesia \\ ${ }^{\left.{ }^{*}\right)}$ h4s.jannah@gmail.com, ${ }^{2)}$ rachmah.ida@fisip.unair.ac.id
}

\begin{abstract}
Abstrak
Penelitian ini mengeksplorasi dan memaknai léncak sebagai salah satu khazanah kekayaan benda-benda berharga warisan para pendahulu dan bisa diproduksi secara turun temurun. Kekayaan yang tersimpan di pulau Madura, baik berupa pandangan, etika, budaya sampai pada kekayaan benda-benda mengandung nilai dan makna sosial bagi kehidupan beragama masyarakat Madura, terutama bagi tokoh agama perempuan Madura. Salah satu benda tersebut bernama léncak, léncak merupakan balai-balai atau tempat duduk yang terbuat dari bambu dan digunakan untuk menerima tamu, di atas léncak inilah para tokoh agama perempuan banyak menghabiskan waktu untuk merumuskan persoalan-persoalan ummatnya, sehingga menjadi perantara ke ruang publik. Penelitian ini menggunakan pendekatan fenomenologi, karena ingin mengungkap tentang makna sosial léncak yang digunakan oleh tokoh agama perempuan Madura dalam menjalankan peran-peran sosial keagamaanya. Penelitian ini menemukan bahwa léncak menjadi ruang bermakna, inspiratif, fasilitatif bagi keberlangsungan negosiasi keagamaan sekaligus menjadi pembuka ruang publik bagi tokoh agama perempuan dengan masyarakatnya.

Kata Kunci: Léncak, Ruang Sosial, tokoh Agama, Perempuan Madura
\end{abstract}




\begin{abstract}
This research explores and interprets léncak as one of the treasures of the treasures of the ancestors' heritage and can be produced from generation to generation. The wealth stored on the island of Madura, both in the form of views, ethics, culture and wealth of objects containing social values and meanings for the religious life of the Madurese community, especially for female religious leaders of Madura. One of these objects was named léncak, because it was on this level that the female religious leaders spent a lot of time formulating the problems of their people, thus becoming intermediaries to the public space. This study uses a phenomenological approach, because it wants to reveal the social significance of the one used by religious leaders of Madurese women in carrying out their religious social roles. This research found that it must be a meaningful, inspirational, facilitative space for the continuation of religious negotiations as well as opening the public space for female religious leaders with their communities.
\end{abstract}

Keywords: Léncak, Social Space, Madurese Female Religion figure.

\title{
Pendahuluan
}

Pulau Madura merupakan pulau yang memiliki beragam khasanah budaya, konstruksi kehidupan sosial, maupun kedalaman cara beragama. Sebagai pulau yang memiliki tingkat religiusitas cukup tinggi, dan diimbangi dengan kekuatan budaya lokalnya, Madura menyimpan banyak potensi kekuatan tradisi yang mengakar pada setiap sendi kehidupan masyarakatnya (Taufiqurrahman, 2007). Karena memiliki kedalaman beragama, maka nuansa kehidupan masyarakat Madura di warnai oleh berbagai ritual kegamaan, sehingga masyarakat Madura menempatkan ulama sebagai tokoh agama sekaligus sebagai pemimpin dan pemandu dalam berbagai ritual keagamaan (Ahmad Zainul, 2018). Ulama memiliki tempat yang spesifik karena disamping urusan perilaku keagamaan, kehidupan sosial masyarakat, juga ulama menjadi tumpuan otoritas. Ulama sebagai perekat solidaritas dalam kegiatan ritual keagamaan dan sebagai pembangun sentiment kolektif keagamaan, sehingga menjadi penyatu elemen-elemen sosial. Sebagai pemegang otoritas keagamaan, keberadaan ulama sangat berpengaruh bagi kehidupan masyarakat Madura (Hefni, 2008; Kuntowijoyo, 1988).

Masyarakat Madura melegitimasi kiai dan nyai sebagai ulama pemegang otoritas, terutama otoritas keagamaan, sehingga peran-peran kiai dan nyai Madura menjadi sangat kompleks. Karena masyarakat Madura mengedepankan nilai-nilai 
agama dalam setiap sendi kehidupannya, maka eksistensi ulama sebagai bagian yang tidak terpisahkan dari struktur sosial setempat. Walaupun ulama secara eksklusif dikenal sebagai pemimpin agama, namun masyarakat Madura menempatkan fungsi ulama pada berbagai lini kehidupan, mulai dari fungsi sosial, budaya, politik, pendidikan dan ekonomi (Lubis \& Nelly, 2018). Menurut Azra (2005) yang menjabarkan bahwa di Indonesia seseorang dipandang sebagai ulama apabila memenuhi beberapa kriteria, antara lain: ahli dalam bidang agama terutama ilmu fikih, mendapat pengakuan dari masyarakat (religio-sosiologis), memiliki integritas yang mencerminkan nilai-nilai keteladanan dalam berperilaku di tengah-tengah masyarakat.

Masyarakat Madura menempatkan ulama pada posisi yang sangat penting dan sentral (Ma’arif, 2015). Mereka tidak hanya dipandang sebagai tokoh yang mengajarkan dan mengamalkan ilmu-ilmu agama saja, tetapi juga sebagai subyek yang mempunyai kekuatan berkah (Berkah merupakan karunia Tuhan yang mendatangkan kebaikan bagi kehidupan manusia yang dijelaskan al-Quran kata dalam surat Al-A'raf: 96 yang berarti kebaikan, keselamatan dan kesejahteraan.) (Nasional, 2008). Tokoh agama perempuan yang dimaksud dalam kajian ini adalah nyai Madura yang memiliki pengetahuan keagamaan, diposisikan sebagai tokoh agama dan tokoh masyarakat, memiliki jamaah pengajian yang cukup signifikan, sebagai pengasuh pondok pesantren, dan eksistensinya sangat berpengaruh diantara perempuan-perempuan Madura. Selama ini tokoh agama perempuan di Indonesia sebagian disandarkan pada sosok nyai, baik nyai sebagai juru dakwah maupun sebagai pengasuh dan pengembang pondok pesantren. Di Indonesia, penelitian tentang nyai cukup variatif, antara lain: nyai sebagai agen perubahan, peranperan nyai dalam kekuasaan di Pondok Pesantren, resistensi nyai, dan lain-lain ('Aeni, 2017; Faiqoh, 2005; Junus, 1999).

Nyai sebagai tokoh agama perempuan dalam pesantren memiliki kemampuan dalam ruang negosiasi untuk berperan dalam ranah publik, baik dalam urusan kepesantrenan maupun kegiatan sosial keagamaan. Pengalaman nyata dari kehidupan perempuan di lembaga yang disebut pesantren menunjukkan hubungan gender yang lebih dinamis dari pada dikotomis, terlepas dari karakter 'patriarki' yang masih melekat pada dunia pesantren. Nyai sebagai bagian tokoh agama di Madura merupakan figur yang sangat strategis dalam pengembangan dakwah Islam di tingkat lokal. Dalam 
banyak hal, mereka dipandang menempati kedudukan dan otoritas keagamaan yang cukup bergengsi sebagai elit agama (Faiqoh, 2005).

Di Madura, gelar nyai di lekatkan pada tokoh agama perempuan yang memiliki kiprah dalam pembentukan masyarakatnya, disamping sebagai istri kiai, dan sebagai anak keturunan seorang ulama terkemuka. Masyarakat Madura memandang nyai sebagai tokoh muslimah yang alim dalam bidang agama, signifikansi peran nyai dalam kehidupan beragama menempatkannya sebagai panutan, khususnya bagi kalangan perempuan Madura. Terlepas dari peruntukan penyebutan nyai tersebut, bahwa sosok nyai bagi masyarakat Madura ditempatkan sebagai sosok perempuan yang terhormat. Walaupun penyebutan istilah nyai di Madura peruntukannya sangat beragam, seperti ada perempuan tua biasa disebut nyai seppo, dimana kapasitasnya sama sekali tidak mengarah pada penguasaan bidang agama, namun karena sudah tua dan sebagai bentuk penghormatan maka seringkali masyarakat memanggilnya nyai. Ada pula penyebutan nyai di peruntukkan pada perempuan yang tidak dikenal atau perempuan yang baru di kenal, namun karena menggunakan kostum sebagimana layaknya sosoknya nyai, maka masyarakat memanggilnya nyai sebagai bentuk penghormatan dan penghargaan. Para Nyai tersebut memiliki pengaruh diantara perempuan-perempuan yang lain dan menjadi teladan kesalehan. Meskipun tidak bisa diabaikan bahwa mereka adalah termasuk dari keluarga besar ulama, namun sebagian besar posisi mereka sebagai pemimpin diperoleh dari hasil usaha mereka sendiri (De Jonge, 1989). Sebagai pemimpin agama dan lembaga keagamaan, nyai Madura berperan secara signifikan dalam mempengaruhi berbagai pilihan hidup masyarakat Madura. Hal ini dapat dicermati pada basis massa yang terakumulasi dalam pesantren, alumni santri dan kelompok pengajian yang tersebar di berbagai pelosok daerah.

Berbagai konstruksi menempatkan tokoh agama perempuan Madura tidak hanya sebagai pemimpin dan pembimbing di bidang ubudiah dan ritual upacara keagamaan saja, namun sering pula diminta kesediaannya untuk menyelesaikan perkara atau kesulitan yang menimpa masyarakat, terutama persoalan perempuan. Peran tokoh agama perempuan Madura semakin mengakar di tengah-tengah masyarakat ketika nasehat-nasehatnya diyakini membawa berkah. Meskipun nyai dikonotasikan sebagai perempuan tradisional, namun keberadaannya tidak dapat digantikan oleh tokoh non 
formal lainnya. Mereka selalu terpanggil pada saat masyarakat dilanda berbagai hajat hidup, mulai dari ritual pernikahan, kelahiran, ritual kematian, pengajian, persoalan perekonomian dan pemecahan masalah dari berbagai konflik hidup.

Kedekatan masyarakat Madura dengan alamnya dalam dimensi kebudayaan tetap terpelihara dengan kuat dan bertahan, sehingga menghasilkan kearifan lokal yang memiliki nilai budaya, sosial, ekonomi dan agama yang cukup tinggi. Dalam kekayaan budaya Madura tersebut kemudian menghasilkan corak batik Madura yang tegas, rumah adat tanean lanjheng, gerabah, perabot ukir, musik, tari, dan tradisi lainnya yang mencerminkan identitas etnik pulau Madura. Hal menarik lainnya yang seringkali luput diangkat dalam kajian tentang Madura adalah, bahwa Madura memiliki benda-benda masa lampau seperti halnya daerah-daerah lain. Benda-benda tersebut sebagian hingga saat ini masih terpelihara dengan baik oleh orang-orang Madura, sehingga menjadi ikon khas Madura yang mengandung nilai-nilai filosofis, juga sebagai bagian dari artefak Madura. Benda-benda tersebut sangat familier dikalangan masyarakat Madura, antara lain panebbha (sapu), are' (clurit), léncak, dan lain sebagainya.

Léncak bagi sebagian masyarakat Madura menjadi barang penting dan berharga yang dapat digunakan dalam berbagai situasi kehidupan masyarakat, terutama bagi tokoh agama perempuan Madura. Keberadaan léncak menghadirkan banyak makna dan fungsi sosial yang sangat nyaman dan bermanfaat dalam komunikasi keagamaan, sosial dan budaya, baik yang bersifat individu maupun kolektif. Mayoritas tokoh agama perempuan Madura memiliki dan menggunakan léncak di rumahnya sebagai tempat untuk menemui tamu-tamunya yang cukup banyak, baik dari kalangan wali santri, jamaahnya, maupun masyarakat umum, sehingga léncak yang disediakan jumlahnya lebih dari tiga. Di léncak inilah para tokoh agama perempuan banyak menghabiskan waktu untuk merumuskan persoalan-persoalan ummatnya

Penelitian ini ingin memaknai léncak sebagai ruang bermakna, inspiratif, fasilitatif bagi keberlangsungan negosiasi keagamaan para tokoh agama perempuan dengan masyarakatnya, hal ini dilakukan di kediaman sang nyai dan akan berlangsung setiap saat, selama sang nyai berada dirumahnya. Maka léncak menjadi ruang yang sangat strategis dalam keberlangsungan negosiasi keagamaan tersebut. Negosiasi 
keagamaan merupakan komunikasi intens antara nyai dengan tamu-tamunya, jamaahnya dan juga wali santri, sehingga menghasilkan energi dan spirit sosial yang sangat penting dalam menyeimbangkan sekaligus mengarahkan pemahaman hidup berbasis agama.

\section{Metode}

Penelitian ini menggunakan pendekatan fenomenologi, pendekatan fenomenologi digunakan untuk memahami pengalaman hidup tokoh agama perempuan Madura lebih mendalam, seperti pengalaman kehidupan sosial, keagamaan dan budaya atau konteks sejarah dimana pengalaman itu terjadi. Maka dalam konteks inilah gagasan Husser ditempatkan, dimana Kesadaran atau pengalaman tokoh agama perempuan digunakan sebagai alat untuk memahami secara lebih baik tentang sosial budaya, politik atau konteks sejarah dimana pengalaman itu terjadi.

Penelitian ini ingin mengetahui pandangan-pandangan, pengetahuan, nilainilai, norma, aturan yang ada dalam suatu masyarakat atau yang dianut oleh individu, dan kemudian dapat menetapkan relasinya dengan perilaku warga masyarakat, perilaku sebuah kolektivitas, atau perilaku individu tertentu. Dengan memusatkan pada pengamatan kehidupan sehari-hari sebagaimana diatur oleh norma atau aturan bersama dalam kelompok sosial tertentu, gejala-gejalanya, dampak-dampaknya diamati dalam struktur kehidupan sehari-hari (individu/masyarakat, aktivitas, etika, estetika, perilaku, relasi, makna dan kepercayaan yang melandasinya).

Dalam metode ini peneliti ingin mengetahui bagaimana struktur pengalaman nyai Madura dalam mengorganisasi realitasnya sehingga menjadi terintegrasi dan autentik. Yakni memahami bagaimana léncak sebagai ruang bermakna, inspiratif, fasilitatif bagi keberlangsungan negosiasi keagamaan bagi tokoh agama perempuan dengan masyarakatnya, hal ini bisa dilihat dalam keseharian, kemudian dipilih, disusun dan ditampilkan sehingga membentuk makna. Pengambilan data diambil dari para nyai Madura sebagai subyek penelitian. Dalam metode ini peneliti ingin mengetahui bagaimana pengalaman nyai Madura dalam mengorganisasi realitasnya sehingga menjadi terintegrasi dan autentik. Pengalaman hidup yang subjektif dari para nyai Madura menjadi sumber data yang sangat penting dalam penelitian ini, sehingga 
membuka ruang kesadaran yang terletak dan melekat pada gejala dan dalam setiap bentuk aktivitas yang disebut intensionalitas, yakni keterarahan kesadaran pada sesuatu, meliputi imajinasi, konsep-konsep dan fantasi tokoh agama perempuan Madura (Karim, 2007).

\section{Dimensi Sosial Léncak dalam Masyarakat Madura}

Léncak merupakan balai-balai, tempat tidur, atau ambin, dan bagian dari perkakas yang berbentuk hamparan persegi empat panjang berkaki empat disetiap pojoknya (Rifai, 2007). Léncak terbuat dari kayu atau bambu, biasa dipakai untuk bekerja, duduk-duduk menerima tamu dan sebagai tempat beristirahat. Namun bagi tokoh agama perempuan Madura, léncak tidak hanya berfungsi sebagai tempat duduk dan beristirahat saja, namun léncak memiliki fungsi sosial keagamaan yang terus dilestarikan. Di ruang tamu rumah nyai Syifak Sampang, nyai Halimah, nyai Tija dan nyai Khairiyyah Pamekasan misalnya, telah tersedia banyak léncak tertata rapi dan dilengkapi dengan berbagai hidangan khas Madura, sebagai bentuk penghormatan terhadap para tamu yang silih berganti mengunjungi sang nyai.

Léncak menjadi tempat sekaligus ruang istimewa bagi para nyai Madura karena disamping telah terbiasa digunakan para leluhurnya, juga membuat nyaman untuk ditempati karena mampu menciptakan suasana non formal, sehingga nyai merasa lebih dekat dengan tamu-tamunya. Demikian juga para tamu tidak akan canggung dalam mengungkapkan persoalan hidupnya, sehingga lebih leluasa mengungkapkan perasaannya pada sang nyai. Makna tersebut secara langsung berhubungan dengan pengalaman-pengalaman nyai Madura dalam menjalankan negosiasi keagamaan mereka melalui kehadiran yang lebih intens, sadar, dan peka dengan masyarakatnya yang berlangsung di atas léncak. Kesadaran bukan dari kenyataan, tapi kesadaran merupakan asal dari kenyataan, di mana obyek-obyek diciptakan oleh kesadaran (Yanuar, 2014), dan dirumuskan sebagai media untuk memeriksa dan menganalisis dimensi sosial léncak yang digunakan oleh tokoh agama perempuan Madura, berupa pengalaman mengenai fenomena atau penampakan sebagaimana adanya, yang lazim disebut kesadaran (Campbell, 1994). 
Fungsi sosial léncak yang digunakan oleh tokoh agama perempuan Madura berupa penasehatan, bimbingan, pelayanan, penyuluhan dan negosiasi dalam memulai atau mencari waktu yang tepat dalam ritual keagamaan (Mardhatillah, 2014). Negosiasi keagamaan tersebut sebagai implementasi hubungan dialogis antara sang nyai yang memiliki otoritas keagamaan dengan ummatnya yang banyak menyandarkan arah hidupnya. Bentuk-bentuk negosiasi keagamaan antara lain berupa penetapan memulai suatu pekerjaan, seperti berlayar bagi para nelayan, membuka toko baru, memulai berangkat belajar, dan lain sebagainya. Penetapan tersebut berdasarkan pada kapasitas representasi kolektif yang mampu melakukan objektivikasi dan rasionalisasi mental dan model (stock of knowledge) yang menjadi tatanan sosial (social order) (Holstein \& Jaber F, 1997).

Aktivitas seorang tokoh agama perempuan cenderung sangat padat seperti, memberi pengajian pada masyarakat luas yang sudah terjadwal dengan rapi, dan itu berlangsung terus menerus. Dalam menyusun jadwal tersebut diperlukan strategi yang disepakati bersama antara sang nyai dengan jamaahnya, dan léncak menjadi benda yang "me-ruang" cukup strategis untuk berlangsungnya komunikasi tersebut. Strategi utama yang digunakan tokoh agama perempuan Madura dalam menjalankan peran-peran sosial keagamaannya adalah strategi dakwah kultural. Dakwah kultural sebagai bentuk kompromi terhadap tradisi memungkinkan dakwah bisa mudah diterima. Masyarakat Madura memandang bahwa antara ketaatan dalam melaksanakan ajaran agama Islam dan melestarikan kepercayaan asli dapat berjalan secara bersamaan (Subaharianto \& Andang, 2004).

Walaupun léncak bukan barang mewah atau mahal, namun bagi nyai Madura, léncak memiliki fungsi sosial yang cukup bermakna karena di dalamnya berlangsung negosiasi keagamaan. Negosiasi keagamaan terletak pada aspek subjektif dari persepsi dan perilaku tokoh agama perempuan Madura tersebut. Léncak sebagai ruang negosiasi keagamaan tokoh agama perempuan Madura merupakan deskripsi pengalaman, penjelasan, dan analisis menyangkut akar realitas dalam praktek sosial sehari-hari yang memungkinkan masuk dalam dunia makna dan dunia praktek kultural yang mengakar. Kemudian menghasilkan data pengalaman, pemikiran, instuisi dan refleksi, sehingga ada koherensi realitas dengan tafsir. 
Menurut Husserl yang dikutip oleh Sindung (Sindung, 2012) bahwa kehidupan menyediakan dasar-dasar harmoni kultural dan aturan-aturan yang menentukan kepercayaan-kepercayaan yang diterima apa adanya (taken forgranted) dalam tata kekuasaan sistematik. Dalam prosedur fenomenologi, yakni dunia yang dialami oleh tokoh agama perempuan Madura dalam keseharian di atas léncak, kemudian dipilih, disusun dan ditampilkan sehingga membentuk makna. Kesesuaian gagasan berjalan dalam pola membuka diri, atau realitas membuka diri, mereka merasa nyaman, percaya diri, dan mandiri dalam melakukan advokasi, penasehatan dan lain sebagainya di atas léncak, sehingga menjadi ruang yang representatif bagi nyai dan tamu-tamunya dalam menyelesaikan persoalan hidup.

Tokoh agama perempuan Madura mampu mengajari dan memberi teladan kepada masyarakatnya. Mereka selalu terpanggil pada ada saat masyarakat dilanda berbagai hajat hidup, mulai dari ritual pernikahan, kelahiran, ritual kematian, pengajian, persoalan perekonomian dan pemecahan dari berbagai konflik hidup. Maka seringkali di atas léncak inilah mampu menciptakan sumber inspirasi yang cukup memadai antara nyai dengan jamaahnya. Artinya ruang lencak menjadi problem solving atas problematika jamaah, sebagaimana diungkapkan nyai Khairiyyah:

"salah satu tamu saya seorang perempuan datang dengan menangis karena persoalan rumah tangganya yang tidak tuntas. Dan di atas léncak ini dia lebih leluasa berterus terang dan saya juga leluasa mencarikan jalan keluarnya."

Apa yang tampak dan dipersepsikan oleh para tokoh agama perempuan Madura merupakan fenomena, dengan melakukan proses "pembiaran" semuanya mengalir begitu saja" (Heidegger, 1962). Karena menyangkut kesadaran dengan segala keluasan dan kedalaman yang berasal dari kenyataan (Yanuar, 2014), maka penelitian ini secara langsung berelasi dengan pengalaman-pengalaman nyai dalam mendapatkan dan menjalan fungsi kesadaran mereka di atas léncak, melalui kehadiran yang lebih intens, sadar, dan peka dengan masyarakatnya.

\section{Léncak: Dari Ranah Domestik Ke Ruang Publik}

Domestik menyangkut kategori sosiologis yang kongkrit karena di dalamnya menyangkut kehidupan sehari-hari, domestik merupakan komponen penting dalam 
membentuk sistem sosial. Domestik seringkali di artikan sebagai kerumahtanggaan yang menyangkut pelayanan (servant) dan cenderung dalam penguasaan majikan. Konotasi domestik bersifat spasial (keruangan) yang di dalamnya berjenjang hal-hal yang berkategori hirarkis. Adanya opini bahwa perempuan berperan dominan dalam urusan domestik, sangat tidak terbantahkan, bahkan sampai domestifikasi. Asumsi ini menggiring pada sebuah pemahaman bahwa domestik diposisikan sebagai institusi yang di dalamnya memainkan sistem patriarki dan mensubordinasi perempuan. Subordinasi menyebabkan posisi perempuan seperti tidak penting dan perlu adanya penolong. Namun asumsi tersebut tidak sepenuhnya benar bila dikaitkan dengan konstruksi léncak dalam keseharian dunia domestik dan publik tokoh agama perempuan Madura. Dalam konsep masyarakat madura ruang domestik merupakan ruang mulia, tempat mengolah sumber kehidupan, dimana di dalamnya mengandung banyak sumbersumber kebaktian, sehingga memunculkan berkah-berkah dalam kehidupan. Sebagaimana diungkapkan oleh salah satu nyai Madura:

"ada kepuasan tersendiri dari dalam diri saya ketika saya bisa menentukan menu makanan keluarga saya, ketika saya mengoleksi pernak-pernik dalam rumah tangga saya, ketika saya bisa menjamu tатu-tamu saya, disini saya bisa berkarya, bekerja, bercerita dan berbuat baik, karena hal ini merupakan dunia saya, yang harus saya jaga dan pelihara, dan seringkali di atas léncak ini saya menemukan dunia saya". (Halimatus, 2018)

Dapat disimpulkan bahwa domestik merupakan ajang mengumpulkan amal kebajikan yang harus dipelihara dan dikuasai perempuan. Ruang domestik merupakan ruang strategis untuk mengaktualisasikan diri, ruang bergembira, dan menciptakan kebahagiaan perempuan. Di dalamnya mampu menghadirkan kepuasan tersendiri jika perempuan bisa meracik ruang domestiknya. Bagi masyarakat Madura, ranah domestik menjadi sumber kemakmuran, karena domestik bukan hanya dapur, kamar dan rumah, tapi juga hal-hal yang menyangkut keterampilan dalam mengelola arus daya sistem sosial dalam menggerakkan masyarakat sehingga bergerak dalam keteraturan sosial. Hal ini dapat dilihat dalam membantu tradisi tengka yang menyangkut tradisi Madura, dalam setiap moment penting mengharuskan perempuan-perempuan Madura terlibat secara total dalam ranah domestik. Dalam moment menjalankan tradisi tersebut, benda 
yang bernama "léncak " akan selalu ada dan menjadi barang penting yang harus tersedia dalam sebuah ritual kelangsungan tradisi (Abdurrahman, 2009).

Para tokoh agama perempuan Madura, seperti di kediaman nyai Syifak, nyai Tije, nyai Halimah dan nyai Khairiyyah begitu menikmati ruang domestiknya, sehingga mereka menata dapur besar keluarganya berdekatan dengan ruang tamu dengan berjejer-jejer léncak, karena tamu-tamunya yang banyak setiap hari, baik tamu wali santri yang ingin nyabis, maupun tamu-tamu masyarakat umum untuk mengundang mengisi ceramah/pengajian. Diruang tamu tersebut banyak disediakan léncak, sebagai simbol otoritas nyai dalam ranah domestik. Dari léncak itulah sang nyai mengendalikan ruang domestiknya sekaligus mengatur ranah publiknya. Kedekatan penataan léncak antara ruang tamu dengan dapur untuk mempermudah sang nyai mengontrol kedua ruang tersebut. Para nyai tersebut sangat menikmati pekerjaan tersebut, karena dengan begitu mereka merasa jhuntrong (semangat/bergairah). Walaupun dalam konsep barat memberikan kritik atas kebahagiaan dan kepuasan perempuan dalam ranah domestik, sebagai sebuah bentuk pembiasaan yang telah lama terkonstruksi pada kaum perempuan sebagai akibat dari dominasi patriarkhi, namun tidak membuat kaum perempuan berpaling dari dunia domestik.

Bagi tokoh agama perempuan Madura urusan domestik sebagai pondasi utama menuju ruang publik, hal ini merupakan satuan sosial yang mampu merekatkan sistem sosial. Asumsinya, urusan domestik merupakan pengetahuan dan pengalaman mendasar yang mengantarkan seorang perempuan memhami dan memaknai hidupnya sebagai wahana menyempurnakan diri. Domestik adalah pondasi utama dalam menggerakkan ruang publik, dan hal itu dikendalikan oleh perempuan. Jadi domestik merupakan ranah aktualisasi dasar perempuan menuju aktualisasi publik. Dalam konsep barat ruang domestik adalah ruang privat, tertutup dan dibelakang. Namun di jawa ruang domestik merupakan ruang terbuka yang menghubungkan ke ruang publik (Permanadeli, 2015). Asumsi dasarnya adalah perempuan bisa masuk dan eksis pada ruang publik, jika sukses mengatur ruang domestik. Dalam pemahaman masyarakat perempuan Madura kesuksesan ruang publik justru membawa keburukan jika urusan domestik terbengkalai. 
Walaupun ranah domestik identik dengan ruang belakang, namun rata-rata nyai madura tidak merasa tersubordinasi, Para nyai sama sekali tidak memandang rendah pekerjaan domestik, bahkan urusan domestik bagi mereka harus dikuasai. Ruang domestik tokoh agama perempuan madura terbagi dalam dua bagian, pertama dalam keluarga, seperti: mengurus anak-anak, mengurus kiai (suami), manajer dalam keluarga, dan mampu menjalani kodratnya. Kedua, dalam Pondok Pesantren, yakni mengasuh pondok pesantren dan manajerial dalam pondok pesantren. Dalam ranah domestik keluarga dan pondok pesantren yang banyak didominasi oleh para nyai, adalah lebih banyak kepada pengendalian dalam sektor ekonomi dan sosial keagamaan. Sebagaimana diungkapkan oleh Nyai Aqidah:

"Tidak ada pembagian apapun dalam urusan rumah tangga maupun pondok pesantren, semuanya mengalir begitu saja, Kiai tidak mengatur saya untuk begini atau begitu, demikian juga saya, malah dalam urusan yang menyangkut keseharian lebih banyak dipercayakan pada saya, sebagaimana yang sering diungkapkannya, terserah apa maunya nyai". (Aqidah, 2018)

Sebagai makhluk sosial yang aktif, tokoh agama perempuan Madura memiliki kesadaran identitas sebagai perempuan Madura, dimana perempuan Madura memiliki tempat utama dalam urusan domestik untuk membuka ruang-ruang publik perempuan. Jika tidak demikian, maka perempuan tersebut dianggap tidak bermasyarakat, tertutup, sehingga mendapatkan sangsi sosial yakni 'ta'ereken' (tidak diperhitungkan) oleh masyarakat.

Perempuan Madura mampu bermain (berkuasa) dalam ruang domestik dan ruang publik, sehingga urusan tekhnis bisa disepakati dengan pasangan, tapi tanggung jawab dan kendali tetap dalam dominasi otoritas perempuan. Kuatnya dikotomi pembagian ruang publik dan domestik-publik, seringkali menempatkan potensi yang dimiliki perempuan untuk beraktivitas sebagai manusia pada ruang sosial dianggap kurang penting. Keberhasilan perempuan dalam ruang publik seringkali dianggap negatif karena keluar dari tugas utamanya dalam urusan rumah tangga, fenomena ini mengharuskan perempuan berperan ganda, artinya perempuan yang aktif diruang publik, harus tetap melakukan pekerjaan domestik. Namun peran ganda tersebut tidak membuat tokoh agama perempuan terkooptasi, karena apa yang diperankan dalam 
ruang domestik tersebut bukanlah sebuah bentuk pengebirian terhadap eksisitensinya sebagai perempuan, bukan pula sebagai beban subordinatif, justru jika peran domestik tidak dilimpahkan kepada mereka, maka mereka merasa haknya dirampas. Hanya saja peran domestik dan peran publik tokoh agama perempuan Madura berbeda dengan perempuan pada umumnya (Syamsuddin, 2015). Secara tehknis mereka dikelilingi oleh fasilitas-fasilitas tenaga sukarela dari asisten, santri atau orang kepercayaan nyai.

Dalam ranah publik, para nyai memiliki kebebasan atas nama dakwah atau syiar agama Islam. Acuannya adalah membolehkan suatu hukum yang sebelumnya terlarang, seperti suara perempuan haram, tapi karena berdakwah, menjadi boleh. Berkumpulnya perempuan-perempuan Madura dalam kelompok pengajian (orang Madura biasa menamakan kamrat/pangajien), sebagai sarana utama para nyai dalam berkomunikasi intens dengan masyarakatnya, dan semua itu dimulai dari léncak. Léncak telah menjadi bagian integral para nyai di Madura sejak dulu hingga kini, dan masih banyak dipertahankan karena mengandung unsur sosial yang berfungsi dalam memulai hingga menjalankan peran-peran penting ketokohan perempuan Madura.

Sebagai tokoh agama dan pemimpin lembaga keagamaan, nyai Madura berperan secara signifikan dalam mempengaruhi berbagai pilihan hidup masyarakat Madura. Hal ini dapat dicermati pada basis massa yang terakumulasi dalam pesantren, alumni santri dan kelompok pengajian yang tersebar di berbagai pelosok daerah. Nyai Madura dipandang pandai menjaga tradisi agama dan kultur Madura sehingga masyarakat menempatkannya sebagai pengendali tradisi téngka (perilaku atau tatakrama yang menjadi hukum adat, bisa juga ditempatkan sebagai sebuah pensikapan yang menghasilkan perilaku). Mereka juga mampu menjadi pemimpin publik seperti organisasi sosial-keagamaan dan tidak lagi dipandang hanya sebagai pendamping kiai, karena ikut berperan aktif dalam memajukan pondok pesantren dan berdakwah dalam ranah publik.

Para tokoh agama perempuan Madura memiliki kharisma di tengah-tengah masyarakatnya sehingga mampu beriringan dengan kharisma kiai, peran sosial keagamaannya juga mampu bersinergi dalam posisi yang cukup strategis dengan kiai, sehingga memiliki ruang otoritas yang signifikan dalam keagamaan, sosial dan budaya. 
Dalam satu desa seorang nyai memiliki kegiatan rutin aktivitas sosial keagamaan hampir tiap hari dengan massa yang cukup banyak, baik dari segi jumlahnya maupun dalam variasi kegiatannya yang cenderung bersifat rutin dan konsisten karena sudah terjadwal dengan sistematis dan bersinergi dengan aktivitas kiai. Dan di atas léncak negosiai publik tersebut banyak dilangsungkan. Signifikansi tokoh agama perempuan dalam berbagai peran tersebut sebagai bentuk partisipasi aktif perempuan dalam agama dan dalam gerakan kesalehan, yang mendorong lahirnya institusi agama formal, seperti organisasi keagamaan, pondok pesantren dan kelompok-kelompok doa. Dalam hal ini perempuan menjadi konstituen signifikan, dimana partisipasinya dalam kesalehan mengubah dan membentuk kesadarannya menjadi lebih terberdayakan. Juga sebagai proses membangun jenis komunitas dan identitas sosial yang baru, sekaligus bisa mengantar ke ruang publik secara lebih luas.

Eksistensi tokoh agama perempuan sebagai energi dan spirit sosial yang sangat penting dalam menyeimbangkan sekaligus menjadi penguat melalui jalur pemahaman dan pendidikan berbasis agama, sehingga nyai sebagai tokoh agama perempuan menjadi juru selamat yang berperan penting dalam pembentukan masyarakat perempuan. Perempuan telah diakui hak-haknya, sehingga dapat belajar, mengukir nasibnya sendiri tanpa di dekte oleh laki-laki. Maka tidak ada lagi halangan bagi perempuan untuk tampil secara terhormat membangun masyarakat, bahkan ummat manusia (Shihab, 2005). Kehidupan perempuan terutama nyai dalam dunia pesantren banyak tidak diketahui publik, seperti adanya pemisahan fisik yang diterapkan di sebagian besar pesantren telah disalah pahami sebagai pembatas pada domain pribadi dari dunia perempuan. Padahal perempuan telah menjadi bagian dari pendidikan pesantren, sebagai murid, instruktur, atau bahkan pemimpin. Namun, dunia pesantren masih mengangkat seperangkat nilai patriarkal, misalnya dalam moment suksesi kepemimpinan dengan memprioritaskan laki-laki sebagai garda terdepan.

Eka Sri Mulyani (2012) telah menununjukkan keterlibatan intensif nyai di ruang publik yang dimungkinkan oleh beberapa faktor, diantaranya kemampuan nyai dan keterampilan yang relevan atau pengalaman serta dukungan kerabat laki-laki (kiai). Gagasan kehormatan mempertahankan dan kerendahan didasarkan pada ajaran Islam dan nilai-nilai pesantren terpelihara dengan baik oleh perempuan-perempuan yang ada 
di pesantren. Walaupun kajian ini tidak menjelaskan secara menyeluruh bentuk-bentuk negosiasi yang digunakan nyai dalam mewujudkan peran publik nyai, namun telah mampu mengungkapkan kontribusi nyai dalam pembentukan karakter santri dan masyarakatnya (Paisun, 2010).

Salah satau kasus yang berkaitan dengan tradisi keagamaan dalam masyarakat Madura, ialah tradisi molodhen (maulid Nabi), ruang kiai sebagai rujukan tradisi keagamaan untuk memelihara budaya tersebut menjadi kewajiban menyelenggarakan molodhen sebagai sikap pemeliharaan status dan transformasi nilai-nilai keagamaan, sehinggga secara normative kiai harus menjadikan acara tersebut sebagai penguatan peran kiai itu sendiri, namun jalanya acara yang berkaitan dengan detail diserahkan sepenuhnya pada sang nyai. Disinilah nyai sepenuhnya sebagai inisiasi dan eksekutor jalannya acara molodhen, dan dengan penuh kesadaran dengan menjaga nama besar seorang kiai adalah bagian dari tradisi keagamaan itu sendiri. Betapa nyai dapat meletakkan porsi keseimbangan dalam struktur masyarakat yang masih terbayangi cara pandang primitive dan bias. Sehingga energi ketokohan nyai Madura mampu difokuskan pada pemberdayaan manusia secara seutuhnya. Walaupun ada sebagian kiai yang menganggap perempuan sebagai kelas kedua setelah kaum laki-laki, sehingga menempatkan nyai harus dibelakang, karena menganggap secara agama seharusnya seperti itu. Hal tersebut diterjemahkan sebagai menjaga marwah kiai sebagai tokoh yang perlu dijaga eksistensinya.

Satu sisi asumsi tersebut dipandang sangat kolot, namun dibalik statemen tersebut sebenarnya tersirat sebuah pengakuan bahwa tanpa adanya sosok nyai yang memiliki kemampuan keilmuan atau tersandang sebagai seorang tokoh agama perempuan dibelakangnya, ada ruang kosong yang tidak mampu di isi oleh seorang kiai dan secara simbolik selalu dapat ditemukan jalan khusus menuju kediaman nyai yang menjadi ruang publik bagi nyai dalam mengkonstruksi peranya sebagai subjek yang independen dan mandiri, tanpa perlu konfirmasi dengan kiai, karena kiai mampu menerjemahkan "Ghulinya " (apa yang dimaksud) nyai. Independensi dan kemandirian nyai dalam peranya sebagai istri kiai merupakan keberhasilan seorang nyai dalam menterjemahkan tradisi dan budaya yang tengah bergulir di masyarakatnya. Tidak perlu ruang terbuka hanya untuk sekedar menunjukan sebuah eksistensi, akan tetapi 
melakukan tindakan tanpa menerjang tradisi dan budaya merupakan salah satu bentuk kecerdasan tersendiri. Justru dalam ruang tertutup nyai mampu keluar dari dimensi ruang itu sendiri sebagai sosok yang lebih akrab dengan masyarakatnya tanpa jarak dan tetap intim. Dengan keintiman tersebut, masyarakat tanpa segan memberikan segalanya pada sosok nyai diruang publik, milik nyai yang biasanya dimulai dalam bentuk sebuah ruang bernama lencak.

Bangunan tradisi dan budaya yang mengakar dalam masyarakat Madura berangkat dari kekuatan tradisi ormas NU dan keagamaan, mampu menjelmakan nyai sebagai seorang tokoh agama perempuan tanpa kehilangan marwahnya sebagai perempuan, dan menjelmakan dirinya sebagai arus kekuatan yang luar biasa dalam alur peradaban dan kebuadayaan lokal Madura. Keintiman tokoh agama perempuan dengan masyarakat mampu mempercepat transformasi seluruh lini keilmuan secara evolusi yang berlangsung cukup kuat, sistematis dan menyeluruh. Mulai dari urusan ibadah, fiqih, syariah, hingga urusan domestik bisa tuntas terselesaikan. Fungsi sosial keagamaan nyai banyak didominasi sebagai tempat pengaduan problem masyarakat dan sebagai pemimpin ritual keagamaan. Aktivitas nyai sebagian cenderung lebih padat dari kiai, sebagaimana diungkapkan nyai Nadimah (salah satu asisiten nyai):

"Nyai saya itu banyak di luar dari pada dirumah, jadwalnya sangat padat, dari jam 9 pagi kadang hingga malam baru bisa kembali ke rumah. Memberi pengajian pada masyarakat luas sudah terjadwal dengan rapi, dan itu berlangsung terus menerus. Selebihnya adalah banyak dihabiskan dengan melayani tamu di rumah, tamu-tamu tersebut menunggu dan bercengkrama di atas lencak".

Bagi Nasaruddin Umar (1999), dalam al-Qur'an tidak ditemukan larangan yang tegas bagi perempuan untuk memilih profesi, selama pekerjaan tersebut halal dan dilakukan dalam suasana terhormat, dan mencegah hal-hal yang yang dapat menimbulkan kemudharatan. Soal peran sosial dalam masyarakat, tidak ditemukan dalam ayat maupun hadis yang melarang perempuan untuk aktif, bahkan sebaliknya alQur'an dan Hadis mengisyaratkan kebolehan perempuan aktif, seperti dalam QS. Attaubah: 71 . 


\section{Léncak sebagai Ruang Budaya Nyabis}

Pada umumnya kaum perempuan Madura menempatkan tokoh agama perempuan sebagai motivator, karena dari para tokoh agama perempuan tersebut munculnya semangat, kegairahan, dukungan sekaligus menjadi kiblat dalam segala aktivitas keseharian. Mereka menjadi inspirator dan teladan bagi kaum perempuan Madura, sehingga ditempatkan sebagai panutan bagi jamaahnya, apa yang tampak, digunakan dan dilakukan oleh para tokoh agama perempuan selalu ditiru dan diteladani, segala apa yang diucapkan dan dilakukan menjadi acuan bagi masyarakatnya, terutama bagi kaum perempuan. Konstruksi religio-sosiologis sosok nyai sebagai tokoh agama perempuan Madura kehadirannya ditengah-tengah masyarakat menjadi spirit pembebasan perempuan Madura dalam menjalankan peranperan sosial keagamaannya, sekaligus sebagai fenomena agama dalam memberikan afirmasi yang signifikan dengan kondisi sosial kultural pada ketokohan perempuan Madura.

Tokoh agama perempuan Madura menjadi panutan bagi kaum Muslim dalam menjalankan syariah dan ibadah sehari-hari serta menjawab persoalan-persoalan sosialbudaya yang dihadapi kaum Muslim, melalui nasehatnya atau pendapatnya. Masyarakat Madura akan mendatangi nyai untuk berkonsultasi, minta petunjuk dan minta diputuskan atas berbagai hajat hidupnya agar sesuai dengan tuntunan agama sehingga tidak melanggar norma Tuhan, tradisi tersebut dalam kultur Madura disebut "nyabis". Sebagaimana diungkapkan oleh asisten nyai Khairiyyah:

"Tamu yang nyabis ke nyai cukup beragam, disamping wali santri ada juga dari masyarakat terpencil atau pedesaan, mereka tidak canggung untuk bercerita dan minta petunjuk atas problem kehidupan mereka. Nyai sangat telaten mendengarkan dan menasehati tamu-tamu tersebut, sehingga betah berlama-lama di atas léncak. Para tamu akan mengikuti semua petuah nyai, karena bagi mereka apa yang disampaikan nyai merupakan petunjuk yang harus diikuti" (Azizah, 2018).

Masyarakat Madura menempatkan tokoh agama perempuan Madura dalam berbagai konstruksi, yaitu konstruksi sejarah, agama, sosial dan budaya. Dalam konstruksi budaya nyai di pandang ajeg dalam menjaga tradisi, dalam konstruksi sosial nyai di tempatkan sebagai sosok kharismatik dalam perekat kehidupan sosial, dalam 
konstruksi agama nyai menjadi juru selamat sekaligus motivator dalam beragama, dan dalam konstruksi produk sejarah, nyai merupakan pewaris lembaga keagamaan yang harus dijaga silsilahnya. Berbagai konstruksi tersebut menempatkan nyai tidak hanya sebagai pemimpin dan pembimbing di bidang ubudiah dan ritual upacara keagamaan saja, namun sering pula diminta kehadirannya untuk menyelesaikan perkara atau kesulitan yang menimpa masyarakat, terutama persoalan perempuan. Peran tokoh agama perempuan Madura semakin mengakar di masyarakat ketika kehadirannya diyakini membawa berkah. Penetrasi Islam yang kuat pada masyarakat Madura membentuk pola hidup yang penuh dengan ritual-ritual keagamaan, mulai dari pendidikan, sosial, ekonomi, bahkan organisasi massa senantiasa berlandaskan pada nilai-nilai keagamaan, sampai oreintasi politiknya, jika tidak demikian maka organisasi tersebut kurang diminati. Konstruksi ketaatan pada agama menjadi pilihan yang tidak bisa ditawar, sehingga kegiatan-kegiatan dalam ritual-ritual keagamaan berkelindan dengan tradisi-tradisi yang mengakar jauh sebelum masuknya Islam di Pulau madura.

Adapun kehidupan eksoterik Islam di Madura, ulama yang mendiami di daerah tertentu di Pulau Madura memperoleh pengesahan sebagai pemilik otoritas, mereka menjadi pemandu untuk mengarahkan jalan hidup masyarakatnya melalui fatwa-fatwa atau pendapat-pendapatnya. Masyarakat Madura akan mendatangi tokoh agama untuk berkonsultasi, minta petunjuk dan minta diputuskan atas berbagai hajat hidupnya agar sesuai dengan tuntunan agama sehingga tidak melanggar norma Tuhan, maka nyabis menjadi ritual yang dilalui oleh masyarakat. Nyabis adalah tradisi berkunjung ke rumah seorang ulama atau guru untuk minta barokah, Nyabis sebagai pintu pembuka untuk minta restu, meminta petunjuk jalan yang diridhai Tuhan melalui petuah-petuah sang guru. Nyabis merupakan hasil konstruksi sosial masyarakat Madura melalui proses obyektivasi, dimana terjadi pelembagaan mengenai hal-hal yang berkaitan dengan nyabis.

Munculnya kesadaran tentang pentingnya sosok ulama atau guru kemudian menghasilkan tindakan nyabis yang termanifestasi sebelum memulai aktivitas penting bagi masyarakat Madura. Tujuannya adalah untuk mencari barokah melalui doadoanya agar apa yang menjadi hajat hidupnya dapat terpenuhi, tanpa kendala sehingga berjalan dengan lancar. Masyarakat Madura yang menjunjung tinggi tradisi ke-Madura- 
an merasa belum sah dan belum percaya diri memulai aktivitas besar semisal perkawinan atau pengajian, sebelum nyabis pada ulama.

Nyai Farideh seorang tokoh agama perempuan Kabupaten Pamekasan menceritakan bagaimana setiap hari didatangi banyak tamu di rumahnya untuk melayani masyarakat yang hendak nyabis, bermacam-macam hal yang dikonsultasikan kepadanya, sehingga Ia menyediakan ruang khusus yang cukup luas. Masyarakat belum puas memulai suatu pekerjaan bila belum di beri petunjuk dan direstui sang nyai. Seseorang yang melakukan nyabis ke rumah seorang tokoh agama akan menampilkan kesopanan yang tinggi baik dalam segi tutur kata maupun cara berbusana, hal tersebut merupakan persona yang harus ditunjukkan kepada ulama. Persona, sangat penting sekali di gunakan oleh orang yang sedang nyabis, karena di situ yang di tampilkan bukan merupakan hakikat diri yang sebenarnya. Artinya, walaupun orang Madura dikenal dengan sikap dan tutur katanya yang sedikit kasar dibanding masyarakat Jawa, tetapi karena adanya tuntutan untuk menampilkan sisi halus, maka orang Madura kemudian menampilkan personanya di hadapan tokoh agama (Lint, 2015). Bahasa yang paling halus digunakan seseorang yang melakukan nyabis dalam menyampaikan hajat hidupnya kepada ulama, pakaian yang sangat sopan yang mencerminkan nilai-nilai islami yang dipadukan kostum kultur Madura, seperti sarung dan peci untuk laki-laki dan baju panjang dan kerudung untuk perempuan. Demikian juga tekstur tubuh membungkuk, menunduk penuh kerendah hatian, merupakan bentuk-bentuk persona bahasa tubuh dalam melakukan tradisi nyabis.

Nyai sebagai tokoh agama menjadi bagian dari seorang ulama, yakni ulama perempuan. Ulama bisa membawa agama untuk kemajuan masyarakat atau justru mereduksi pesan-pesan agama. Hal Ini tergantung pada perspektif keagamaankeagamaan yang diyakini, oleh sebab itu ulama menjadi pusat dialektika perubahan masyarakat. Di tangan ulama tergenggam dua otoritas keagamaan, yakni sebagai penafsir otoritatif atas teks-teks suci dan penjaga moral keagamaan (Muhammad, 2004). Nyai menjaga determinasi kepercayaan masyarakat sebagai wakil khusus Tuhan dengan melakukan proses pemahaman apa yang diinginkan Tuhan dengan apa yang dibutuhkan masyarakat. Bagi masyarakat madura hanya ulama yang mampu menjembatani dua kepentingan tersebut, kemampuan tersebut merupakan otoritas yang 
dimiliki ulama. Maka hubungan yang terbangun antara masyarakat madura dengan ulama adalah hubungan yang "khas", dan kemudian menjadi identitas etnik (Subaharianto \& Andang, 2004). Ada beberapa perempuan yang berbeda dengan perempuan pada umumnya, mereka merasa gelisah pada nasib kaumnya, dan mereka melakukan langkah yang berbeda, maka ulama perempuan mampu dan berani membuat keputusan danmembuat langkah yang tidak lazim (Rengkaningtias, 2018; Yafie, 2017).

\section{Simpulan}

Nyai sebagai tokoh agama perempuan Madura, memiliki kontribusi yang sangat berarti dalam pembentukan masyarakatnya. Mereka tidak hanya sebagai pemimpin dan pembimbing di bidang ubudiah dan ritual upacara keagamaan saja, namun menjadi pemandu untuk menyelesaikan perkara atau kesulitan yang menimpa masyarakat, terutama persoalan perempuan. Nyai Madura sebagai tokoh agama perempuan Madura mempunyai karakter sosial dan budaya yang cukup spesifik. Mereka mempunyai jati diri dan motivasi yang kuat sehingga membentuk motivasi intrisik yang unik dan khas yang menggambarkan nilai-nilai religiusitasnya yang melekat dalam kehidupan seharihari, sehingga berpengaruh cukup dominan dalam pembentukkan identitas budayanya. Dalam ajaran turun temurun yang kemudian dikemas dalam ideologi agama menempatkan nyai sebagai tokoh perempuan Madura untuk mentradisikan kepatuhan dan ketaatan dalam beragama, hal tersebut menjadi pembuka bagi nyai Madura untuk berkiprah dalam spektrum yang lebih luas, dengan mengatasnamakan syiar agama.

Léncak menjadi ruang bermakna bagi nyai sebagai tokoh agama perempuan Madura, dalam mengelola kebutuhan jamaah, santri dan masyarakatnya. Léncak menjadi ruang representative bagi sang nyai untuk melakukan negosiasi intens antara nyai dengan masyarakatnya, dimana di dalamnya ada ruang kebebasan untuk melayani para tamu yang menginginkan pemahaman berbasis agama, sehingga menguatkan legitimasi otoritas sosial keagamaan nyai. 


\section{Referensi}

'Aeni, F. N. (2017). Dinamika Kepemimpinan Nyai di Pesantren Budaya Jawa. Martabat Jurnal Perempuan dan Anak, 1(1). http://doi.org/10.21274/martabat.2017.1.1.65-86

Abdurrahman. (2009). Analisa Sosial dan Membangun Madura Pasca SURAMADU. Karsa, 14(2). http://doi.org/http://dx.doi.org/10.19105/karsa.v16i2.107

Ahmad Zainul, H. (2018). Dinamika Hubungan Islam dan Lokalitas: Perebutan Makna Keislaman di Madura. Teosofi: Jurnal Tasawuf dan Pemikiran Islam, 8(2). http://doi.org/https://doi.org/10.15642/teosofi.2018.8.2.430-454

Aqidah. (2018). Nyai dalam Lingkaran Pesantren. Madura.

Azizah. (2018). Sikap Nyai dalam Konteks Sosial. Madura.

Azra, A. (2005). Jaringan Ulama Timur Tengah dan pepulauan Nusantara Abad XVII \& XVIII. Jakarta: Prenada Media.

Campbell. (1994). Tujuh Teori Sosial. Yogyakarta: Kanisius.

De Jonge, H. (1989). Madura dalam Empat Zaman: Perdagangan, Perkembangan Ekonomi, dan Islam. Jakarta: Gramedia.

Faiqoh. (2005). Nyai Agen Perubahan di Pesantren. Penelitian Pendidikan Agama dan Keagamaan, 3(2). http://doi.org/http://dx.doi.org/10.32729/edukasi.v3i2.212

Halimatus. (2018). Peran Perempuan di Madura. Sumenep.

Hefni, M. (2008). Local Knowledge Masyarakat Madura: Sebuah Strategi Pemanfaatan Ekologi Tegal Di Madura. Karsa, 2(1).

Heidegger, M. (1962). Being and Time (terjemahan). New York: Herper dan Row.

Holstein, J. A., \& Jaber F, G. (1997). Strategies of Inquiry. In Phenomenology, Ethnomethodology and Interpretive Practices. New York: American Press.

Junus, U. (1999). Nyai Dasima and the Problem of Interpretation: Intertextuality, Reception Theory, and New Historicism. Humaniora, 11(3). http://doi.org/https://doi.org/10.22146/jh.674

Karim, A. J. (2007). Kepemimpinan Wanita Madura Hasil Penelitian Dukungan SosialBudaya Terhadap Keberhasilan Kepemimpinan wanita "Srikandi" di Desa Pademawu BaratKabupaten PamekasanMadura. Mimbar, 23(2).

Kuntowijoyo. (1988). Perubahan Sosial dalam Masyarakat Agraris: Madura 1850-1940. Yogyakarta: PAU Studi Sosial UGM.

Lint, L. (2015). Aplikasi teori Jung pada budaya Madura “nyabis dha' dhalemma keyae." 
Lubis, H., \& Nelly, R. (2018). Komodifikasi Otoritas Kiai dalam Kontestasi Politik (Studi Komodifikasi Otoritas Kiai di Kec. Pasen Kabupaten Pamekasan). Jurnal Sosiologi Pendidikan Humanis, 3(2).

Ma'arif, S. (2015). The History Of Madura: sejarah panjang Madura dari Kerajaan, Kolonialisme sampai Kemerdekaan. Yogyakarta: Araska.

Mardhatillah, M. (2014). Perempuan Madura sebagai Simbol Prestise dan Pelaku Tradisi Perjodohan. Musawa: Jurnal Studi Gender dan Islam, 13(2).

Muhammad, H. (2004). Islam Agama Ramah Perempuan Pembelaan Kyai Pesantren. Yogyakarta: LKiS.

Nasional, D. P. (2008). Kamus Besar Bahasa Indonesia. Jakarta: Gramedia Pustaka Utama.

Paisun. (2010). Dinamika Islam Kultural: Studi atas Dialektika Islam dan Budaya Lokal Madura. el-Harakah, 12(2).

Permanadeli, R. (2015). Dadi Wong Wadon, Representasi Sosial Perempuan Jawa Di Era Modern. Yogyakarta: Pustaka Ifadah.

Rengkaningtias, A. U. (2018). Wacana Keulamaan Perempuan Dalam Teks Ikrar Kebon Jambu. Musawa: Jurnal Studi Gender dan Islam, 17(1). http://doi.org/https://doi.org/10.14421/musawa.1.171.32-50

Rifai, M. A. (2007). Manusia Madura: Pembawaan, Perilaku, Etos Kerja, Penampilan dan Pandangan Hidupnya, seperti Dicitrakan Peribahasanya. Yogyakarta: Pilar Media.

Sindung, H. (2012). Spektrum Teori Sosial dari Klasik hingga Postmodern. Yogyakarta: Ruzz Media.

Subaharianto, \& Andang. (2004). Tantangan Industrialisasi Madura: Membentur kultur, Menjunjung Leluhur. In Madura- Perubahan Sosial. Malang: Banyumedia.

Syamsuddin, M. (2015). Elit Lokal Madura: Sisi Kehidupan Kaum Blater. Jurnal Lektur Keagamaan, 13(1). http://doi.org/http://dx.doi.org/10.31291/jlk.v13i1.208

Taufiqurrahman. (2007). Identitas Budaya Madura. Karsa, 11(1). http://doi.org/DOI: http://dx.doi.org/10.19105/karsa.v11i1.143

Yafie, H. A. (2017). Jejak Perjuangan Keulamaan Perempuan Indonesia. Jakarta: Kongres Ulama Perempuan Indonesia (KUPI).

Yanuar, I. (2014). Metode Penelitian Sosial Kualitatif. Bandung: Rafika Aditama. 